\title{
Catchment liming creates recolonization opportunity for sensitive invertebrates in a smelter impacted landscape
}

\author{
John M. GUNN, ${ }^{*}$ Brian W. KIELSTRA, ${ }^{2}$ Erik SZKOKAN-EMILSON ${ }^{3}$ \\ ${ }^{1}$ Cooperative Freshwater Ecology Unit, Vale Living with Lakes Centre, Laurentian University, 935 Ramsey Lake Rd., Sudbury, ON, \\ Canada; ${ }^{2}$ Department of Forest and Conservation Sciences, University of British Columbia, Vancouver, Canada VGT $124 ;{ }^{3}$ Ecosystems \\ and Global Change Group, Department of Plant Sciences, University of Cambridge, Downing Street, Cambridge CB2 3EA, UK \\ *Corresponding author: jgunn@laurentian.ca
}

\begin{abstract}
The response of a sensitive indicator species to the effects of catchment liming was assessed in a lake severely impacted by atmospheric emissions from a metal smelter in Sudbury, Canada. The lake chemistry recovered following the closure of the local smelter and major reductions (approximately 95\%) in acid and metal emissions from other area smelters, leading to recolonization of the lake with fish and other biota. However, the littoral macrobenthos community remain severely impoverished. The catchment liming sustained improved stream water quality for 20 years after the initial aerial treatment and created a littoral zone hot spot for the recolonization of Hyalella azteca. Colonization at delta sites of untreated catchment drainage areas, in the same lake, were low and highly variable, and these sites appeared to be impacted from soil erosion and episodic release of acid and metals. This study demonstrated the need to both reduce air pollutants and to conduct land reclamation in severely damaged watersheds, before lake ecosystems themselves can be fully recovered.
\end{abstract}

Key words: Smelter; Hyalella azteca; land reclamation; liming.

Received: February 2015. Accepted: April 2015.

\section{INTRODUCTION}

In areas affected by acid deposition, terrestrial catchment liming has often been used to increase the duration of the neutralizing treatment for downstream aquatic systems, or to reduce the episodic nature of acid runoff events (Hindar, 2005; Hindar and Wright, 2005). Outside of concerns about impacts to vegetation, such as the loss of sphagnum moss or other acidophilus plants, catchment liming has usually been considered a very effective means of chemical treatment of the recipient water bodies (Clair and Hindar, 2005). However, the goals of these management treatments have rarely been broadened beyond this chemical focus, to consider how catchment treatments can enhance other terrestrial inputs or subsidies to lakes and streams. For example, many recent studies have shown that terrestrial catchments contribute much of the productivity of small low nutrient lakes through the release of dissolved or fine particulate organic matter that fuels the aquatic food web (Cole et al., 2006; Jansson et al., 2007; Karlsson et al., 2012). In addition to the nutrient inputs, coarse woody debris released into the aquatic system also generates habitat and substrates that attract and support a vast array of microbial, invertebrate and vertebrate species (Willis and Magnuson, 2000; Roth et al., 2007; Kreutzweiser, et al., 2008) that make delta areas and littoral zones such highly productive ecosystems (Roach et al., 2014). Re-establishing these land water linkages is therefore an important management goal when considering options for severely damaged landscapes.

This study documents the chemical trends and biotic responses to catchment liming in a once very acidic and metal contaminated lake near an abandoned metal smelter in Sudbury, Canada. It is part of a much larger study of the land water linkages that operate to aid in the recovery of severely damaged systems (Szkokan-Emilson et al., 2011; Tanentzap et al., 2014). Our study updates an earlier paper that focused on the immediate chemical changes that accompanied catchment liming (Gunn et al., 2001). Here we take a much longer perspective (20 years), and demonstrate the importance of restoring healthy terrestrial ecosystems to benefit downstream aquatic systems and their biotic communities. We use an indicator species approach and focus on restoration of a key member of the organic matter scraper and shredder community, Hyalella azteca, a ubiquitous but sensitive amphipod that is absent from the littoral zones of many acid and metal contaminated lakes in the greater Sudbury area (Wesolek et al., 2010a), a loss that contributes to the low productivity of these nearshore areas in contaminated lakes (Sherwood $e t$ al., 2002; Luek et al., 2013). Hyalella azteca cannot survive in lakes with a pH below approximately 5.6 (Snucins, 2003), and is further limited by its high sensitivity to metals even at higher $\mathrm{pH}$ levels (Borgmann et al., 2005). 


\section{Study lake and experimental catchment treatment area}

Daisy Lake is a 36 ha oligotrophic (total $\mathrm{P}<10 \mu \mathrm{g} \mathrm{L}^{-1}$ ), dimictic lake, with a maximum depth of $14 \mathrm{~m}$. It is a long, narrow lake that extends 3.5 to $6.5 \mathrm{~km}$ southwest of the abandoned Coniston $\mathrm{Cu}$ and $\mathrm{Ni}$ smelter that had operated from 1913 to 1972 (Fig. 1). When our monitoring studies began in the early 1990s the lake was very acidic $(\mathrm{pH}<5.0)$ and metal contaminated $\left(\mathrm{Cu}>70 \mu \mathrm{g} \mathrm{L}^{-1} ; \mathrm{Ni}>300 \mu \mathrm{g} \mathrm{L}^{-1}\right)$. It was fishless and lacked many species of sensitive macroinvertebrates (clams, snails, and amphipods (including $H$. azteca) typically found in the littoral zone (Wesolek et al., 2010a). Based on sediment pollen records the original pine (Pinus spp.) and spruce (Picea spp.) dominated forest was lost in the 1940s resulting in extensive soil erosion that left much of the watershed consisting of blacked exposed bedrock (Dixit et al., 1996). Today, now more than 40 years since the closure of the local smelter, a distinct spatial pattern to the damage has developed across the 275 ha watershed. In the east, closer to the old smelter site, the land is still nearly completely barren. As you move to the west, progressively more white birch (Betula papyrifera), trembling aspen (Populus tremuloides), red pine (Pinus resinsa), and red oak (Quercus rubra) occur, particularly in sheltered valleys with thicker soils and in moist lowlands (SzkokanEmlison et al., 2011).

While the overall forest cover of the Daisy Lake watershed has been very slow to recover, and soil erosion and low organic soil content remain persistent problems (SARAG, 2009), the water chemistry in the lake has improved greatly in response to very large atmospheric emission reductions from the metal processing industry in Sudbury. In addition to the closure of the Coniston smelter, total emissions of $\mathrm{SO}_{2}$ and metal particulates have been reduced by approximately $95 \%$ since the early 1960 s, a pe-

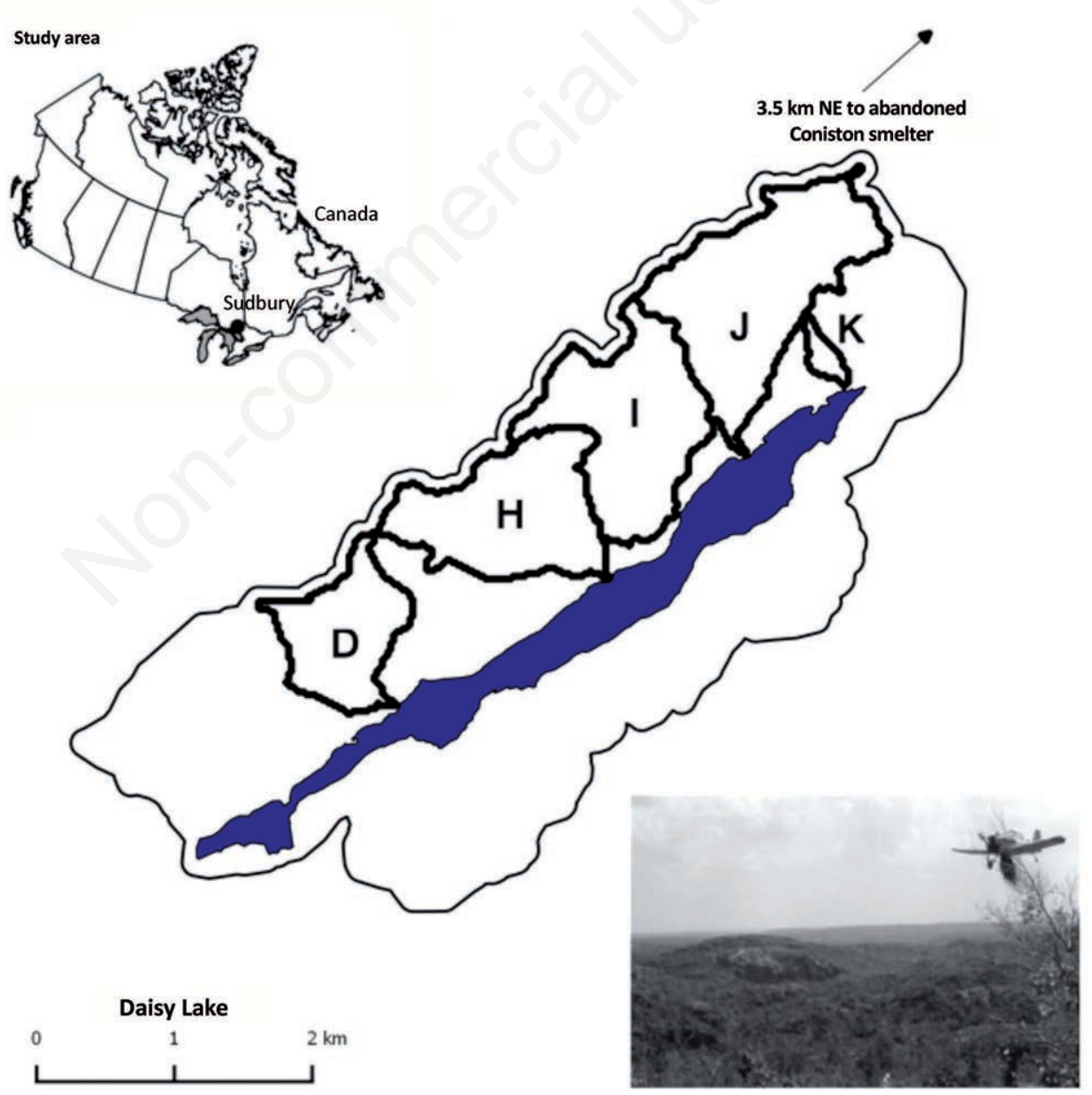

Fig. 1. Daisy Lake watershed near the abandoned Coniston Smelter in Sudbury, Ontario, Canada. The entire 275 ha watershed is delineated and five catchment study sites (2-39 ha) are shown. The treatment catchment ( $\mathrm{J})$ used for an experimental liming project in the mid 90's is labelled. Inserted is a photo of an airplane applying limestone to the treated catchment (J) in 1994 (Photo: W. Keller). 
riod when the Sudbury smelters represented the largest source of $\mathrm{SO}_{2}$ in the world (Fig. $2 \mathrm{~A}$ ). The $\mathrm{pH}$ and dissolved organic carbon (DOC) concentration in Daisy Lake began increasing about 1990, while metal concentration declined (Fig. 2 B,C,D) and a wide variety of fish species (including: northern pike (Esox Lucius), white sucker (Catostomus commersoni), walleye (Sander vitreus), yellow perch (Perca flavescens) and smallmouth bass (Micropterus dolomieu) have since invaded the lake from the downstream lake, which in turn has permitted fish feeding birds [common loon (Gavia immer)] to resume reproduction. However, these improvements to the fish and avian species did not include the littoral benthos, where recovery was very delayed and appeared to be impacted by continued acid and metal contaminated drainage water from the terrestrial catchment areas (Wesolek et al., 2010b). Repeated surveys between 1990 and 2007 detected no H. azteca in Daisy Lake (Watson, 1992; Mantysaari and Vine, 2004; Wesolek et al., 2010a) until about 2010, the year when the first specimens were detected near the outlet of the lake (Fig. 2B). Phylogenetic analysis indicated that these colonists were of the same clade as those that occupied the downstream circumneutral lake, suggesting that this lake was the likely source of the colonists moving into Daisy Lake (Babin-Fenske et al., 2012).

Within the Daisy watershed there are 13 individual catchment areas, drained by ephemeral streams which run only in the spring and fall or during particularly heavy rain events in summer. The 39 ha Site $\mathrm{J}$ catchment area, selected for liming (Fig. 1), was located in the most devastated area closest to the smelter, and prior to treatment the stream water from this catchment had consistently low $\mathrm{pH}$ (approximately 4.5) low base cation concentrations ( $\mathrm{Ca} 1.7$ $\left.2.5 \mathrm{mg} \mathrm{L}^{-1}\right)$ and high metal concentrations $(\mathrm{Cu} 56-138 \mu \mathrm{g}$ $\mathrm{L}^{-1}$; Ni 320-354 $\mu \mathrm{g} \mathrm{L}^{-1}$ ) (Gunn et al., 2001; Tab. 1). The experimental catchment was aerially limed in 1994 using 410 tonnes of coarse dolomitic limestone $\left(53.9 \% \mathrm{CaCO}_{3}\right.$; $48.8 \% \mathrm{MgCO}_{3}$ ) applied evenly across the full catchment area, and 54 tons of fine pelletized dolomite $(54.5 \%$ $\mathrm{CaCO}_{3} ; 45.0 \% \mathrm{MgCO}_{3}$ ) applied to the 15 small wetland areas (at 31.8 tons per ha) within the catchment in 1995 (Gunn et al., 2001).
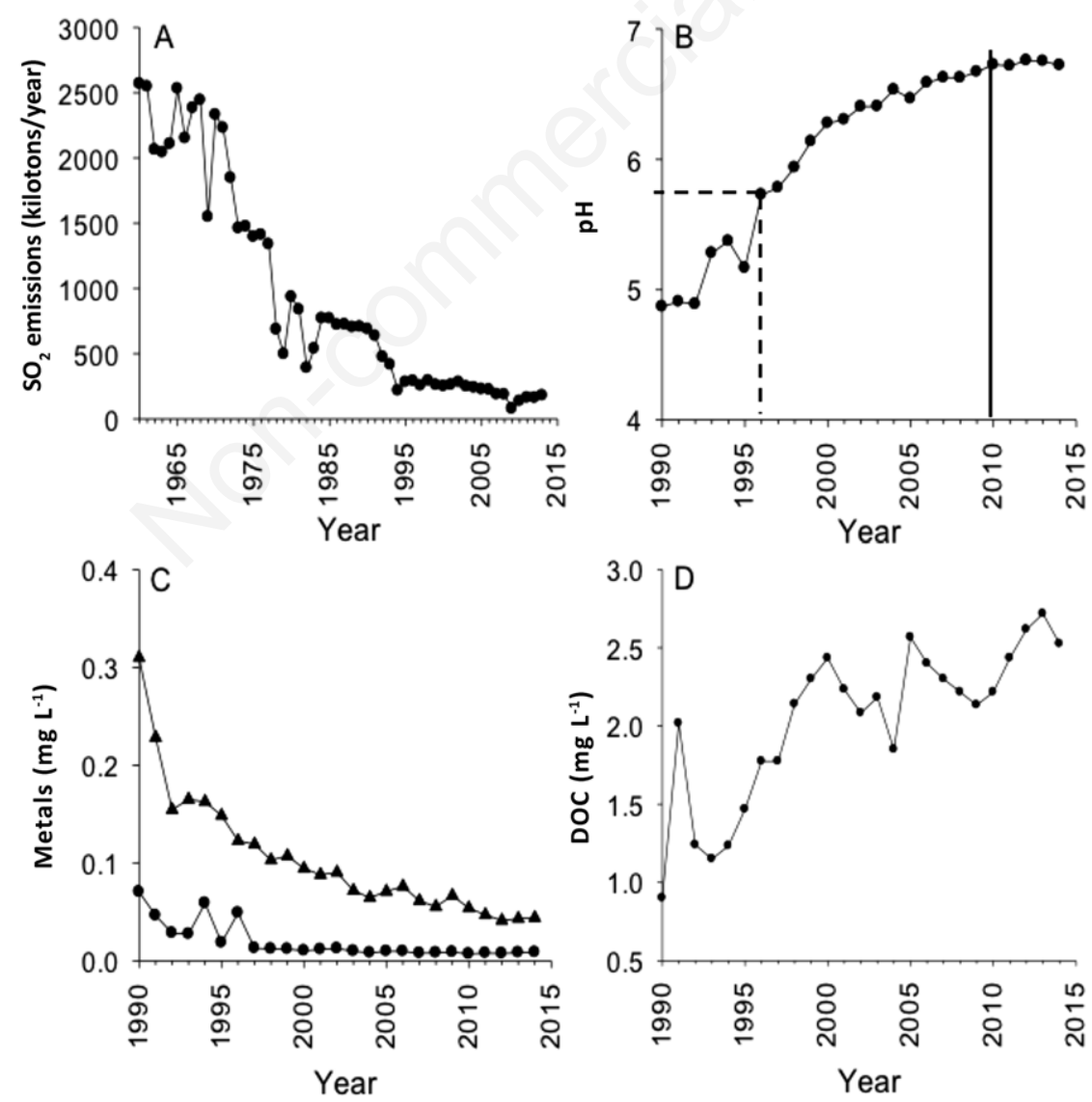

Fig. 2. A) Decline in $\mathrm{SO}_{2}$ emissions from Sudbury smelters. B) Increase in mid-lake pH in Daisy Lake. Date of the lake reaching expected $\mathrm{pH}$ threshold for amphipod survival (- - - -) and timing of actual colonization (- - ) indicated. C) Decline in metal concentrations and (D) increase in DOC (with metal binding capabilities) illustrated. 


\section{METHODS}

We selected 4 reference catchments located along the north shore of Daisy Lake (D, H, I, K) to contrast with the limed catchment (J) (Fig. 1). These catchments have been previously delineated and characterized using topography, satellite imagery, and aerial photography classifications (Kielstra, 2014) (Tab. 2). Stream water grab samples were collected from approximately $15 \mathrm{~m}$ above the site where the catchment streams discharged into Daisy Lake beginning in 1990. Most samples $\left(\mathrm{n}=3-21 \mathrm{yr}^{-1}\right)$ were collected in May and June before streams dried up for the season. All samples were analyzed for $\mathrm{pH}, \mathrm{ANC}$, colour, conductivity, metals (total $\mathrm{Al}, \mathrm{Cu}, \mathrm{Ni}, \mathrm{Pb}, \mathrm{Zn}, \mathrm{Fe}, \mathrm{Mn}$ ), major ions ( $\mathrm{Ca}, \mathrm{Mg}, \mathrm{Na}$, $\mathrm{Cl}, \mathrm{SO}_{4}, \mathrm{SiO}_{3}$ ) and nutrients (DOC, $\mathrm{P}, \mathrm{N}$ ) at the Ontario Ministry of the Environment laboratory (1981). H. azteca were collected using modified Hester-Dendy artificial substrates (hereafter, dendies), using standard protocols (NTL-LTER, 2005). Dendies $(n=6-8)$ were deployed at the delta areas (within the lake) at the mouths of the drainage streams, and were spaced $1 \mathrm{~m}$ apart following transects at the $0.75 \mathrm{~m}$ depth contour at each site. In very flat shallow deltas, dendies were spaced along the depth contour at $5 \mathrm{~m}$ perpendicular from shore (depth range: $0.25-0.75 \mathrm{~m}$ ). Dendies were deployed in August at a time when the streams them- selves were usually not running, except after heavy rain events, but the delta areas were visibly enriched with organic matter and debris that had been discharged to these sites from the adjoining catchment area during earlier periods of stream flow. The dendies were left undisturbed and then retrieved after ca. 25 days, then filtered on a $500 \mu \mathrm{m}$ sieve, preserved in $70 \%$ ethanol, and amphipods were identified and counted under a dissecting microscope (MZ16 1-40x, Leica Microsystems Canada Inc., Ontario, Canada).

We used Poisson Generalized Linear Mixed Models (GLMMs) to associate $H$. azteca abundance (number per dendy) with both stream chemistry and catchment variables (Zuur et al., 2013). Stream chemistry variables included $\mathrm{pH}, \mathrm{DOC}, \mathrm{Al}, \mathrm{Cu}, \mathrm{Ni}$ and watershed variables included subcatchment area, \% wetlands as defined using a threshold of the compound topographic wetness index, $\%$ barren cover estimated using multispectral aerial photograph classification, and the mean NDVI (Normalized Difference Vegetation Index; a measure of forest density) across maximum value composites generated using Landsat imagery (Kielstra, 2014). Wetlands and barren areas were derived using higher resolution data input versus NDVI (i.e., $10 \mathrm{~m}$ digital elevation model, 0.4 multispectral image, and $30 \mathrm{~m}$ pixel sizes, respectively) in order to better resolve landscape fea-

Tab. 1. Selected chemical variables for stream water quality from the 5 catchment areas on Daisy Lake during the final study years (2013-2014) of the amphipod colonization study. For the limed catchment (J), conditions immediately pre- (1991-1992) and post-liming (1996-1997) are also shown (mean \pm SD indicated).

\begin{tabular}{|c|c|c|c|c|c|c|c|}
\hline & \multicolumn{3}{|c|}{ Limed catchment (J) } & \multicolumn{4}{|c|}{ Reference catchments } \\
\hline & $\begin{array}{l}\text { Pre-liming } \\
\text { (1991-1992) }\end{array}$ & $\begin{array}{l}\text { Post-liming } \\
\text { (1996-1997) }\end{array}$ & $\begin{array}{l}\text { Post limed } \\
(2013-2014)\end{array}$ & \multicolumn{3}{|c|}{ (2013-2014) } & K \\
\hline & $\mathrm{n}=\mathbf{2 1}$ & $n=31$ & $n=9$ & $n=9$ & $\mathrm{n}=\mathbf{1 0}$ & $\mathrm{n}=10$ & $n=9$ \\
\hline $\mathrm{pH}$ & $4.44 \pm 0.07$ & $5.73 \pm 0.50$ & $6.78 \pm 0.19$ & $5.53 \pm 0.58$ & $5.92 \pm 0.23$ & $4.79 \pm 0.23$ & $4.59 \pm 0.11$ \\
\hline $\mathrm{ANC}\left(\mathrm{mg} \mathrm{L}^{-1}\right)$ & $-2.01 \pm 0.50$ & $1.07 \pm 0.36$ & $6.85 \pm 1.53$ & $4.3 \pm 4.62$ & $2.33 \pm 1.50$ & $-0.17 \pm 0.63$ & $-0.5 \pm 0.44$ \\
\hline $\mathrm{Ca}\left(\mathrm{mg} \mathrm{L}^{-1}\right)$ & $1.63 \pm 0.33$ & $4.83 \pm 1.29$ & $2.39 \pm 0.38$ & $2.24 \pm 1.49$ & $2.03 \pm 0.23$ & $1.07 \pm 0.27$ & $0.933 \pm 0.15$ \\
\hline $\mathrm{DOC}\left(\mathrm{mg} \mathrm{L}^{-1}\right)$ & $1.44 \pm 0.41$ & $1.99 \pm 0.55$ & $4.28 \pm 1.27$ & $3.08 \pm 2.05$ & $2.64 \pm 0.70$ & $2.75 \pm 1.21$ & $0.922 \pm 0.26$ \\
\hline $\mathrm{Cu}\left(\mathrm{mg} \mathrm{L}^{-1}\right)$ & $0.13 \pm 0.02$ & $0.02 \pm 0.01$ & $0.02 \pm 0.01$ & $0.01 \pm 0.003$ & $0.01 \pm 0.003$ & $0.026 \pm 0.01$ & $0.037 \pm 0.004$ \\
\hline $\mathrm{Ni}\left(\mathrm{mg} \mathrm{L}^{-1}\right)$ & $0.3 \pm 0.05$ & $0.07 \pm 0.02$ & $0.03 \pm 0.01$ & $0.1 \pm 0.01$ & $0.11 \pm 0.02$ & $0.085 \pm 0.01$ & $0.102 \pm 0.01$ \\
\hline $\mathrm{Al}\left(\mathrm{mg} \mathrm{L}^{-1}\right)$ & $1.36 \pm 0.28$ & $0.13 \pm 0.09$ & $0.12 \pm 0.04$ & $0.21 \pm 0.04$ & $0.12 \pm 0.05$ & $0.235 \pm 0.02$ & $0.58 \pm 0.06$ \\
\hline
\end{tabular}

Tab. 2. Landscape characteristics of five catchments in Daisy Lake's watershed. All variables were input into separate GLMMs. Mean catchment NDVI (Normalized Difference Vegetation Index) was generated using Landsat 5 images. Barren area was estimated using multispectral aerial photo classification, and wetland area was estimated using pixels above a threshold of the compound topographic wetness index derived from digital elevation models (from Kielstra, 2014).

\begin{tabular}{|c|c|c|c|c|c|c|}
\hline Site & Area (ha) & NDVI & Barren area $(\%)$ & Wetland area (\%) & Barren area (ha) & Wetland area (ha) \\
\hline $\mathrm{D}$ & 18.48 & 0.65 & 31.97 & 1.18 & 5.7 & 0.19 \\
\hline $\mathrm{H}$ & 29.14 & 0.67 & 26.55 & 2.81 & 7.5 & 0.87 \\
\hline $\mathrm{J}$ & 39.34 & 0.64 & 34.33 & 3.84 & 13.4 & 1.57 \\
\hline $\mathrm{K}$ & 1.95 & 0.55 & 46.08 & 0.00 & 0.89 & 0.00 \\
\hline
\end{tabular}


tures that may not be differentiated by satellite imagery alone. We standardized predictors to mean of zero and unit variance. Due to multicollinearity of predictors and limited sample size, we compared models with a single predictor, controlling for variation in the amount of $H$. azteca sampled per year (i.e., fixed effects of predictor and year). Site (e.g., $\mathrm{D}, \mathrm{H}, \mathrm{I}, \mathrm{J}, \mathrm{K}$ ) was included as a random intercept. We used an additional observation-level random effect to account for overdispersion. Chemistry and watershed models were compared separately using $\mathrm{AIC}_{\mathrm{c}}$ (Akaike's Information Criteria; using form corrected for small sample size bias) to generate the best predictive candidates (Burnham and Anderson, 2002). GLMMs were fit using lme4 version 1.0-6 and compared using MuMIn version 1.9.13 in $R$ version (Barton, 2013; Bates et al., 2014; R Core Team, 2014).

\section{RESULTS AND DISCUSSION}

Liming of catchments and their wetlands can in some cases result in an initial pulse of metals, as the added base cations exchange with soil-bound metal cations
(González-Alcarez et al., 2013). This initial spike in metal concentrations was noted from the limed catchment $(\mathrm{J})$ in this study as well, but this spike subsided within a few weeks to be followed by significantly improved water quality (Gunn et al., 2001). The liming of the J catchment in 1994/95 has sustained improved stream water chemistry for 20 years (Fig. 3), and achieved desired water quality conditions for biota (e.g., $\mathrm{pH}>6.0)$ long before emission reduction alone would have been effective. For example in catchment I (Fig. 1), the adjoining untreated reference catchment, mean $\mathrm{pH}$ increased slowly (from 4.5 to 4.8), $\mathrm{Cu}$ decreased (from 56 to $23 \mathrm{ug} \mathrm{L}^{-1}$ ), Ca decreased (from 2.5 to $1.2 \mathrm{mg} \mathrm{L}^{-1}$ ), and DOC increased (from 1.9 to $2.3 \mathrm{mg} \mathrm{L}^{-1}$ ) during this same 1991-2014 period (Fig. 3). Changes in these parameters are consistent with recovery trends observed in other regions where acid deposition has been reduced (Keller et al., 2001; Monteith et al., 2007; Jeziorski et al., 2008). However, the observed magnitude of water quality improvements in the catchment I reference stream, brought about by emission reductions
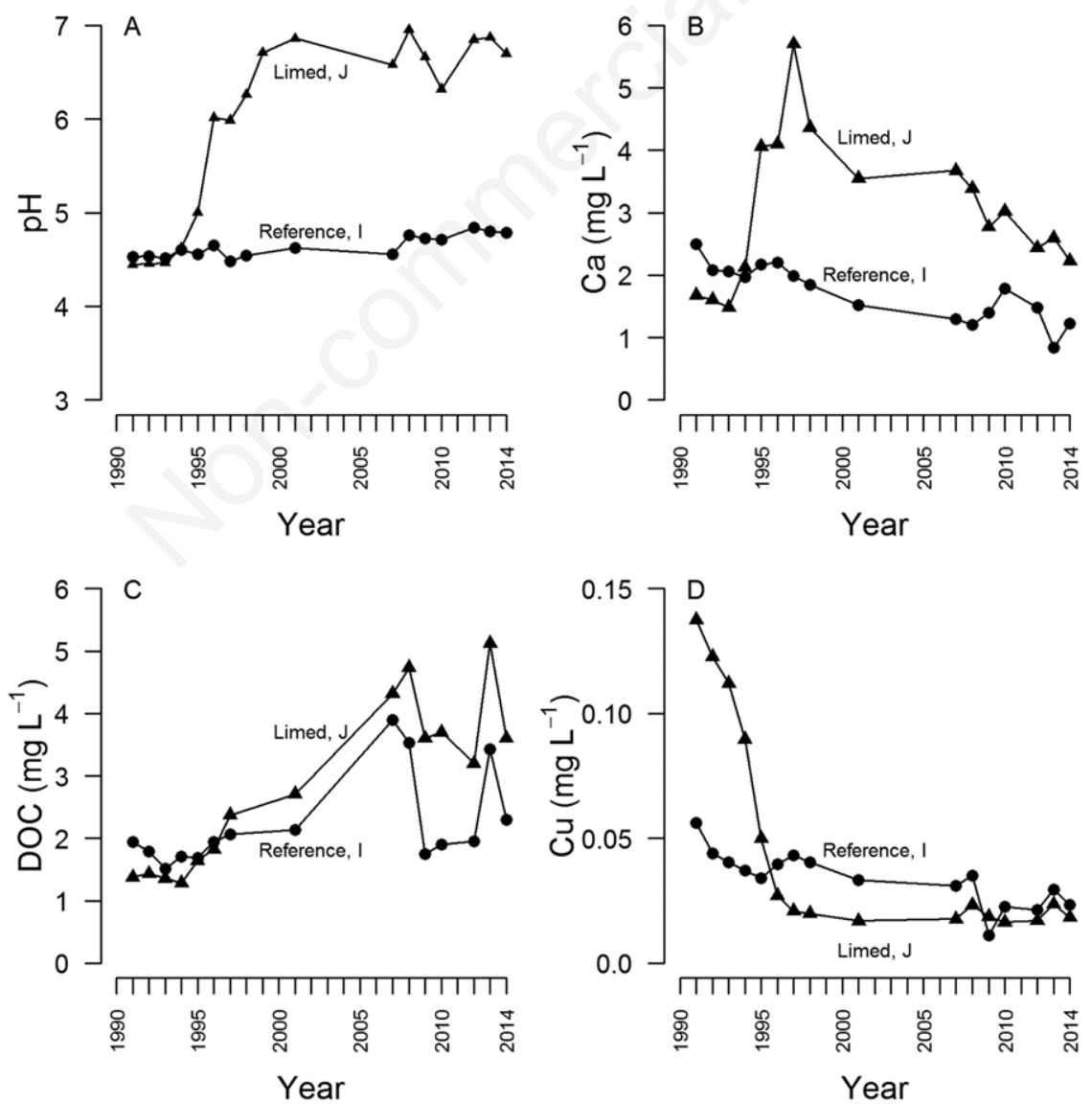

Fig. 3. Trends in mean chemistry for the reference (circles, catchment I) and limed (triangles, catchment J) catchments. Trends are separated by variables of interest including $\mathrm{pH}$ (A), calcium (B), dissolved organic carbon (C), and copper (D) concentrations. Mean values are shown. Error bars were left out for clarity (see Tab. 1 for description of current conditions in the remaining reference catchments). 
alone, were not sufficient to eliminate the predicted toxicity of acid and metals in these dilute waters in Sudbury (Welsh et al., 1993).

From an ecosystem perspective the real benefit of the catchment liming was not that of improving water quality conditions in the ephemeral drainage streams themselves, but rather in changes observed at the confluence sites of the receiving water, Daisy Lake. Here we note that the catchment liming created habitat conditions at its delta area within the lake that have favoured the colonization of a highly sensitive indicator species, $H$. azteca (Fig. 4). In 2011 single specimens of $H$. azteca were collected for the first time at sites D and J, the two deltas associated with catchments with circumneutral steam water (one by liming, the other naturally occurring); however the development of an abundant population of amphipods over the next 3 years $(2012,2013,2014)$ was much greater at the limed catchment site (Fig. 4).

We have two hypotheses to explain the pattern of colonization at the 5 study sites, the first being a toxicological hypothesis related to the periodic releases of fine sediments and acid and metal rich stream water from catchments to the delta sites. In support of this hypothesis we found a strong negative association between the average $H$. azteca abundance in the dendies and total Al concentration in stream water (Fig. 5; Tab. 3). Al concentration was also positively correlated $(\mathrm{P}<0.05$, Spearman's rho: 0.73 ) with the percentage of the catchment area that was bare, and negatively correlated $(\mathrm{P}<0.05$, Spearman's rho: -0.64 and -0.73 respectively) with catchment area and NDVI as a measure of forest cover. The dendies were in place during the summer period when streams were usually not flowing, and one would then expect that with currents and wind mixing all shoreline sites would be exposed to very similar circumneutral lake water chemistry. However in each year indi-

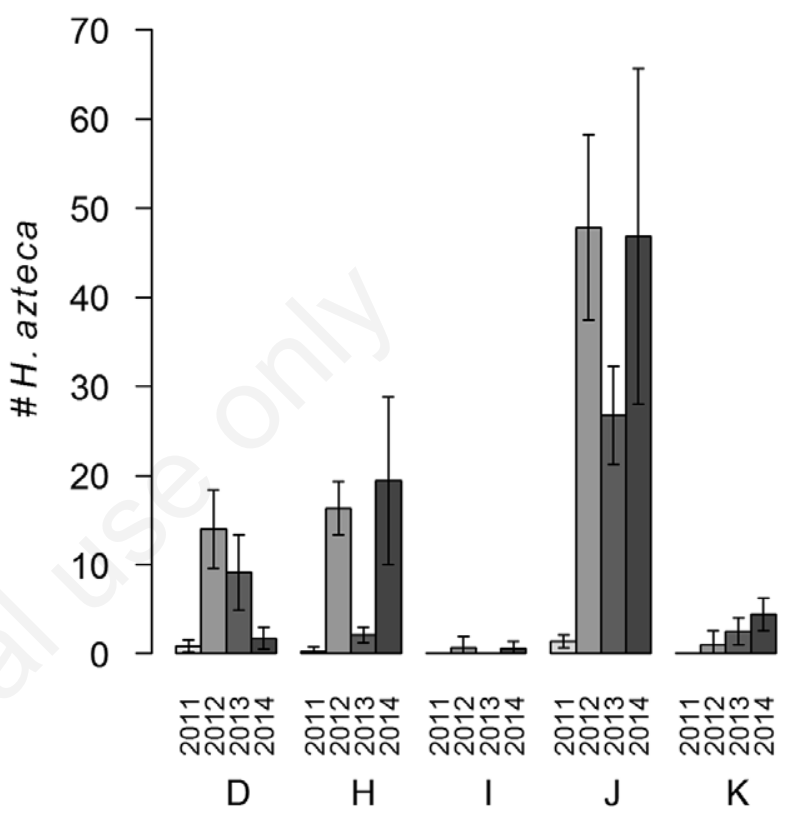

Fig. 4. Abundance estimates of Hyalella azteca separated by catchment (D, H, I, J, K) and study year (2011-2013). Error bars represent the $95 \%$ confidence intervals about the sample means.
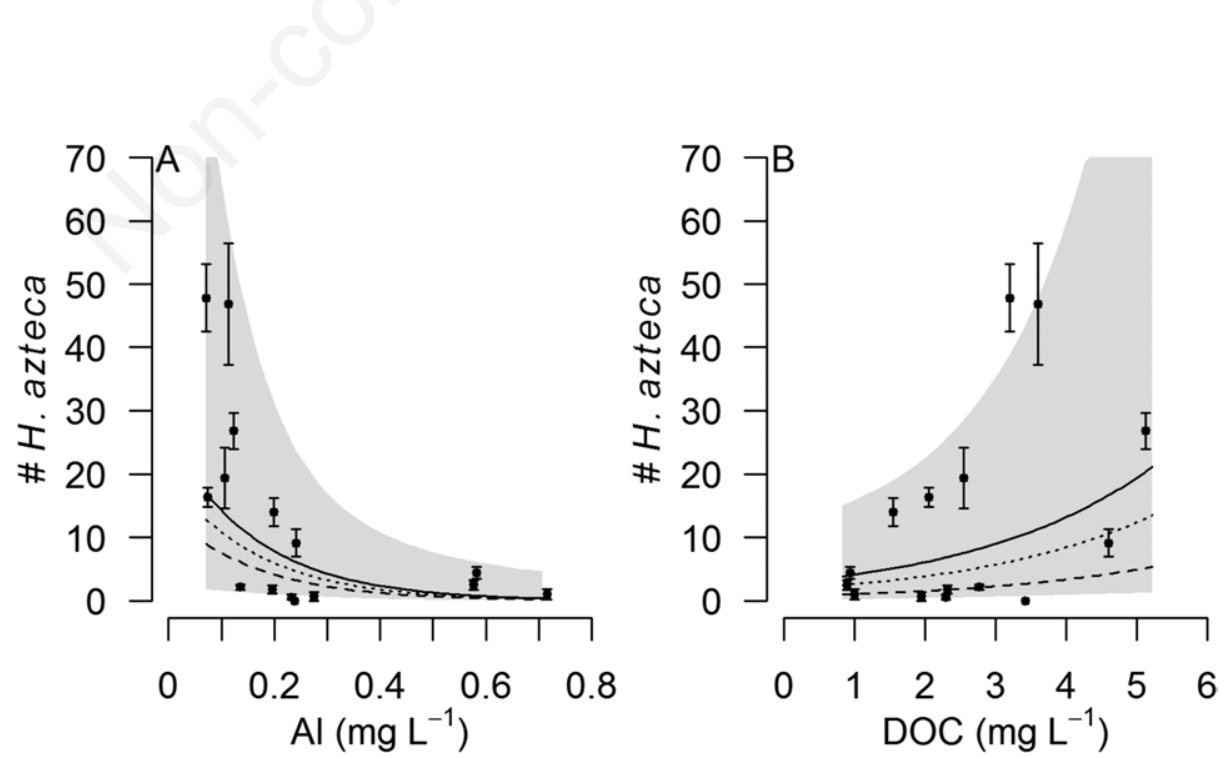

Fig. 5. Hyalella azteca abundance in dendies associations with measured Al concentrations (A) and DOC concentrations (B) in catchment stream water. Lines are fitted regressions where the intercept varies in a given year; 2012 is solid, 2013 is dashed, and 2014 is dotted. Grey polygons represent the area covered by the combined $95 \%$ confidence intervals of the individual regression lines. This does not incorporate uncertainty in the random effects. Means of all sites (by site and by year) are plotted together and error bars represent $95 \%$ confidence intervals about the sample means. 
vidual heavy rain events did occur and these events may have released pulses of acid metal rich water that created toxic mixing zone conditions (Rosseland et al., 1992) within the deltas at the sites where dendy counts were low. We do not have any in-lake measure of the duration or extent of such toxic plumes, but Szkokan-Emilson et al. $(2013,2014)$ noted high temporal variability in stream water chemistry draining from two of the catchments used in our study ( $\mathrm{I}$ and $\mathrm{H}$ ), with high concentrations of metals released during rain events in the summer months. We therefore hypothesize that periodic rain events during our study may have caused direct mortality of amphipods and/or led to precipitation of fine erosional sediments or solutes that coated substrates and organic matter and prevented colonization by amphipods. Wesolek et al. (2010b) found extensive coats of fine $\mathrm{Al}$ rich erosional material on leaf packs that he employed in Daisy Lake. Scanning electron microscopy revealed that this material was mainly feldspar and quartz. Fe precipitates where also observed below wetlands during drought periods at Site I, a catchment where almost no amphipods colonized the delta area (Fig. 4). Such precipitates are known to impact invertebrate and microbial communities (Siefert and Mutz, 2001; Holland et al., 2014).

The second hypothesis is that the improved terrestrial catchment conditions, either through the catchment liming treatment and subsequent vegetation growth, or because of better residual soil conditions at individual catchments such as Site H, led to greater organic enrichment of individual delta sites. This enrichment may have then attracted and supported more colonizing amphipods. In support of this organic enrichment hypothesis we did find the strongest positive association between $H$. azteca abundance and stream water DOC concentration (Fig. 5; Tab. 3).
We did not find strong direct associations between amphipods abundance in the delta areas and measured catchment variables, presumably because of the small number of sites involved. However, DOC in stream water was positively correlated $(\mathrm{P}<0.05$, Spearman's rho: 0.69$)$ with catchment area. Consistent with our findings, SzkokanEmilson et al. (2011) found that increased fine-particulate organic matter export from the catchment areas was associated with increased overall diversity of nearshore macroinvertebrate communities in Daisy Lake. Tanentzap et al. (2014) then showed that the export of DOC from catchments in Daisy Lake led in steps as an upsurge in energy through bacterial, and zooplankton and eventually led to greater growth of larval perch at sites associated with higher forest cover. Although the improvements to terrestrial catchment conditions did appear to be associated with improved overall aquatic community health in the deltas, through the release of organic matter and other terrestrial subsidies, it remains likely that the mitigation of toxicological impacts brought on by liming is still having the greatest beneficial effects on H. azteca, given their known sensitivity to low $\mathrm{pH}$ and metals.

\section{CONCLUSIONS}

The catchment liming experiment that began 20 years ago was designed to address a very narrow management goal of finding a more cost effective and long term treatment of acidified catchments to assist in the neutralization of receiving water bodies. The massive reductions of acid and metal particulate emissions in Sudbury has in the meantime created widespread water quality improvements in area lakes, perhaps lessening the need for further testing of this technology here, or elsewhere in the world where

Tab. 3. GLMM results associating Hyalella azteca abundance with chemistry and watershed variables. Coefficients with $95 \%$ bootstrapped confidence intervals (bCI) are presented on the natural logarithmic scale. The intercept-only model with random effects is presented for comparison. $\mathrm{AIC}_{\mathrm{c}}$ is Akaike's Information Criterion with small sample size correction. Marginal GLMM $\mathrm{R}^{2}\left(\mathrm{R}_{\mathrm{m}}^{2}\right)$ is explained variance using fixed effects only while conditional GLMM $\mathrm{R}^{2}\left(\mathrm{R}_{\mathrm{c}}^{2}\right)$ uses random effects.

\begin{tabular}{|c|c|c|c|c|c|c|c|}
\hline GLMM & Fixed & $\begin{array}{l}\text { Coefficients } \\
(95 \% \text { bCI) }\end{array}$ & Random & $\begin{array}{l}\text { Variance } \\
\text { component } \\
(95 \% \mathrm{bCI})\end{array}$ & $\mathbf{A I C}_{\mathrm{c}}$ & $\mathbf{R}_{\mathrm{m}}^{2}$ & $\mathbf{R}^{2}{ }_{c}$ \\
\hline Null & Intercept & $1.33(0.71,1.47)$ & $\begin{array}{c}\text { Site } \\
\text { Dendy }\end{array}$ & $\begin{array}{l}2.62(2.16,7.56) \\
0.70(0.63,1.23)\end{array}$ & 613.74 & 0 & 0.74 \\
\hline $\begin{array}{l}\text { Model } \\
\text { (chemistry) }\end{array}$ & $\begin{array}{c}\text { Intercept (2012) } \\
\text { Al } \\
2013 \\
2014\end{array}$ & $\begin{array}{c}1.70(1.07,1.92) \\
-1.21(-2.17,-0.56) \\
-0.64(-1.05,-0.26) \\
-0.27(-0.66,0.10)\end{array}$ & $\begin{array}{c}\text { Site } \\
\text { Dendy }\end{array}$ & $\begin{array}{l}2.16(1.65,6.99) \\
0.52(0.42,0.97)\end{array}$ & 603.36 & 0.32 & 0.83 \\
\hline $\begin{array}{l}\text { Model } \\
\text { (watershed) }\end{array}$ & $\begin{array}{c}\text { Intercept (2012) } \\
\text { DOC } \\
2013 \\
2014\end{array}$ & $\begin{array}{c}2.02(1.27,2.33) \\
0.49(0.09,0.93) \\
-1.37(-2.01,-0.72) \\
-0.45(-0.84,-0.02)\end{array}$ & $\begin{array}{c}\text { Site } \\
\text { Dendy }\end{array}$ & $\begin{array}{l}2.01(1.47,6.53) \\
0.50(0.41,0.98)\end{array}$ & 605.44 & 0.10 & 0.79 \\
\hline
\end{tabular}


similar improvements have been made. However, this experiment has demonstrated the importance of land management in initiating recovery of severely disturbed ecosystems (Kozlov and Zvereva, 2007) and has revealed some of the key terrestrial/aquatic linkages between healthy land and healthy water that have wide application.

\section{ACKNOWLEDGMENTS}

We acknowledge field assistants from the Cooperative Freshwater Ecology Unit at Laurentian University and Ontario Ministry of the Environment and Climate Change for conducting the chemical analyses. We also thank Michelle Gillespie for helping to compile datasets for this study. Funding was provided through an NSERC Collaborative Research and Development grant with industrial partners including the City of Greater Sudbury, Vale and Glencore. The authors declare no conflict of interest.

\section{REFERENCES}

Babin-Fenske JJ, Meritt TJS, Gunn JM, Walsh T, Lesbarrères D, 2012. Phylogenetic analysis of Hyalella colonization in lakes recovering from acidification and metal contamination. Can. J. Zool. 90:624-629.

Barton K, 2013. MuMIn: Multi-model inference. R package ver. 1.9.13. Available from: http://CRAN.R-project.org/package= MUMIn

Bates D, Maechler M, Bolker B, Walker S, 2014. Lme4: Linear mixed-effects models using Eigen and S4. R package ver. 1.06. Available from: http://CRAN.R-project.org/package=lme4.

Borgmann U, Nowierski M, Dixon DG, 2005. Effects of major ions on the toxicity of copper to Hyalella azteca and implications for the biotic ligand model. Aquat. Tox. 73:268-287.

Burnham KP, Anderson DR, 2002. Model selection and multimodel inference: A practical information-theoretical approach. Springer, New York: 488 pp.

Clair TA, Hindar A, 2005. Liming for the mitigation of acid rain effects in freshwaters: A review of recent results. Environ. Rev. 13:91-128.

Cole JJ, Carpenter SR, Pace ML, Van de Bogert MC, Kitchell JL, Hodgson JR, 2006. Differential support of lake food webs by three types of terrestrial organic carbon. Ecol. Lett. 9:558-568.

Dixit AS, Dixit SS, Smol JP, 1996. Setting restoration goals for an acid and metal-contaminated lake: a paleolimnological study of Daisy Lake (Sudbury, Canada). Lake Reserv. Manage. 12:323-330.

González-Alcarez MN, Conesa HM, Álvarez-Rogel J, 2013. When liming and revegetation contribute to the mobilisation of metals: learning lessons for the phytomanagement of metal-polluted wetlands. J. Environ. Manag. 116:72-80.

Gunn JM, Sein R, Keller B, Beckett P, 2001. Liming of acid and metal contaminated catchments for the improvement of drainage water quality. Water Air Soil Pollut. 130:1439-1444.

Hindar A, 2005. Whole-catchment application of dolomite to mitigate episodic acidification of streams induced by seasalt deposition. Sci. Tot. Environ. 343:35-49.

Hindar A, Wright RF, 2005. Long-term records and modelling of acidification, recovery, and liming at Lake Hovvatn, Norway. Can. J. Fish. Aquat. Sci. 62:2620-2631.

Holland A, Duivenvoorden LJ, Kinnear SHW, 2014. Influence of Aldrich humic acid and metal particulates on survivorship of mayflies (Atalophlebia spp.) to acid mine drainage. Environ. Tox. Chem. 33:567-572.

Jansson M, Persson L, De Roos AM, Jones RI, Tranvik LJ, 2007. Terrestrial carbon and intraspecific size-variation shape lake ecosystems. Trends Ecol. Evol. 22:316-322.

Jeziorski A, Yan N, Paterson A, DeSellas A, Turner M, Jeffries D, Keller W, Weeber R, McNicol D, Palmer M, McIver K, Arseneau K, Gin B, Cumming B, Smol J, 2008. The widespread threat of calcium decline in freshwaters. Science 322:1374-1377.

Karlsson J, Berggren M, Ask J, Bystrom P, Jonsson A, Laudon H, Jansson M, 2012. Terrestrial organic matter support of lake food webs: Evidence from lake metabolism and stable hydrogen isotopes of consumers. Limnol. Oceanogr. 57:1042-1048.

Keller W, Dixit SS, Heneberry J, 2001. Calcium declines in northeastern Ontario lakes. Can. J. Fish. Aquat. Sci. 58:2011-2020.

Kielstra BK, 2014. Thinking outside the lake: Multiple scales of amphipod recovery. M.Sc. Thesis, Queen's University.

Kozlov MV, Zvereva EL, 2007. Industrial barrens: extreme habitats created by non-ferrous metallurgy. Rev. Environ. Sci. Biotechnol. 6:231-259.

Kreutzweiser DP, Good KP, Capell SS, Holmes SB, 2008. Leaflitter decomposition and macroinvertebrate communities in boreal streams linked to upland logging disturbance. J. NA Benthol. Soc. 27:1-15.

Luek A, Morgan GE, Wissel B, Gunn JM, Ramcharan CW, 2013. Impaired littoral energy pathways cause a shift to pelagic resources by fish in recovering lake food webs. Ecol. Fresh. Fish. 22:348-360.

Mantysaari D, Vine L, 2004. Increasing colonization of the amphipod (Hyalella azteca) in Sudbury area lakes; evidence of biological recovery. BSc Thesis, Laurentian University.

Monteith DT, Stoddard JL, Evans CD, de Wit HA, Forsius M, Høgånsen T, Wilander A, Skjelkvåle BL, Jeffries DS, Vuorenmaa J, Keller B, Kopácek J, Vesely J, 2007. Dissolved organic carbon trends resulting from changes in atmospheric deposition chemistry. Nature 450:537-540.

NTL-LTER, 2005. North Temperate Lakes LTER: Benthic macroinvertebrates 1981-2004, Wisconsin, US: Available from: http://lter.limnology.wisc.edu/dataset/north-tenperatelakes-lter-benthic-macroinvertebrtaes-1981-2004.

Ontario Ministry of the Environment, 1981. Handbook of analytical methods for environmental samples. Government of Ontario, Canada: 243 pp.

R Core Team, 2014. R: A language and environment for statistical computing. R Foundation for Statistical Computing, Vienna, Austria. Available from: http:/www.R-project.org

Roach KA, Winemiller KO, Davis SE, 2014. Autochthonous production in shallow littoral zones of five flood plain rivers: effects of flow, turbidity and nutrients. Freshwater Biol. 58:1278-1293.

Roth B, Kaplans L, Sass G, Johnson, P, Marburg A, Yannarell A, Havlicek T, Willis T, Turner M, Carpenter S. 2007. Linking terrestrial and aquatic systems: the role of woody habitat in lake food webs. Ecol. Modell. 2003:439-452.

Rosseland RO, Blakar IA, Kroglund F, Kvellstad A, Lydersen 
E, Ougton DH Salbu B, 1992. The mixing zone between limed and acidic river waters: complex aluminum chemistry and extreme toxicity for salmonids. Envionr. Pollut. 78:3-8.

Sherwood GD, Kovecses J, Hontela A, Rasmussen JB, 2002. Simplified food webs lead to energetic bottlenecks in polluted lakes. Can. J. Fish. Aquat. Sci. 59:1-5.

Siefert J, Mutz M, 2001. Processing of leaf litter in acid waters of the post-mining landscape in Lasatia, Germany. Ecol. Eng. 17:297-306.

Snucins E, 2003. Recolonization of acid-damaged lakes by the benthic invertebrates Stenacron interpunctatum, Stenonema femoratum and Hyalella azteca. Ambio 32:225-229.

SARAG, Sudbury Area Risk Assessment Group, 2009. Volume III: Ecological risk assessment. SARA Group, Sudbury, Canada. Available from: http://www.Sudburyssoil.com/En/indexE.htm.

Szkokan-Emilson EJ, Wesolek B, Gunn JM, 2011. Terrestrial organic matter as subsidies that aid in the recovery of macroinvertebrates in industrially damaged lakes. Ecol. Appl. 21:2082-2093.

Szkokan-Emilson EJ, Kielstra B, Watmough S, Gunn J, 2013. Drought-induced release of metals from peatlands in watersheds recovering from historical metal and sulphur deposition. Biogeochemistry 116:131-145.

Szkokan-Emilson EJ, Watmough SA, Gunn JM, 2014. Wetlands as long-term sources of metals to receiving waters in min- ing-impacted landscapes. Environ. Poll. 192:91-103.

Tanentzap AJ, Szkokan-Emilson EJ, Kielstra BW, Arts MT, Yan ND, Gunn JM, 2014. Forests fuel fish growth in freshwater deltas. Nat. Commun. 5:4077.

Watson GB, 1992. Factors affecting the distribution of the freshwater amphipod (Hyalella azteca) in Sudbury area lakes. BSc Thesis, Laurentian University.

Welsh PG, Skidmore JF, Spry DJ, Dixon DG, Hodson PV, Hutchinson NJ, Hickie BE, 1993. Effect of $\mathrm{pH}$ and dissolved organic carbon on the toxicity of copper to larval fathead minnow (Pimephales promelas) in natural lake waters of low alkalinity. Can. J. Fish. Aquat. Sci. 50:1356-1362.

Wesolek BE, Genrich EK, Gunn JM, Somers KM, 2010a. Use of littoral benthic invertebrates to assess factors affecting biological recovery of acid- and metal-damaged lakes. J. N. Am. Benthol. Soc. 29:572-585.

Wesolek BE, Szkokan-Emilson EJ, Gunn JM, 2010b. Assessment of littoral benthic invertebrate communities at the landwater interface in lakes recovering from severe acid- and metal-damage. Hum. Ecol. Risk Assess. 16:536-559.

Willis TV, Magnuson JJ, 2000. Pattterns of fish species composition across the interface between streams and lakes. Can. J. Fish. Aquat. Sci. 57:1042-1052.

Zuur A, Hilbe J, Ieno E, 2013. A beginner's guide to GLM and GLMM with R. Highland statistics: 253 pp. 